\title{
ANALISA PROSES KOMUNIKASI ATAS NORMALISASI KONSEP PANOPTICON DALAM ORGANISASI BHAYANGKARI
}

\author{
Phopy Harjanti Bulandari \\ phoveldy@gmail.com \\ Mahasiswa Program Pascasarjana Ilmu Komunikasi Universitas Diponegoro
}

\begin{tabular}{|c|c|}
\hline Article Info & Abstract \\
\hline $\begin{array}{l}\text { Keyword: } \\
\text { panopticon, symbolic violence, } \\
\text { women organization, vertical } \\
\text { communication, patriarchy culture. }\end{array}$ & $\begin{array}{l}\text { This article discusses the panopticon mechanism happened in Bhayangkari-an } \\
\text { organization of wives of police in Indonesia. By using case study, this article focuses } \\
\text { to see the system and the role of mode of communication that done by members of } \\
\text { Bhayangkari. Theory of symbolic violence applied to explain how women were } \\
\text { controlled and were became the victim of the panopticon in this organization. This } \\
\text { research found that women in Bhayangkari proud to be controlled and pressed under } \\
\text { the normative role of the organization with patriarchal culture. It is reflected in the } \\
\text { way they wear dress, how they conduct vertical communication, as well as how they } \\
\text { express themselves in social media. Furthermore, those particular behaviors were } \\
\text { done in order to gain prestige and pride of Bhayangkari woman. Finally, this } \\
\text { research concluded that Bhayangkari women did not realize that the practice of } \\
\text { panopticon mechanism happened in their organization. They did not aware that } \\
\text { patriarchy culture has controlled them and defined them as the victim of symbolic } \\
\text { violence. }\end{array}$ \\
\hline
\end{tabular}

Copyright (C) 2018 Interaksi: Jurnal Ilmu Komunikasi.

\section{PENDAHULUAN}

Panopticon bisa dibaca sebagai sebuah desain sosial, yang implikasinya pada masyarakat modern menjadi metafora atas pola "pendisiplinan" menggunakan perangkat atau sistem pengawasan. Adapun Panopticon ini, selain memiliki kecenderungan yang menyebar, keberadaanya memiliki fungsi untuk mengawasi dan menormalisasi dalam sebuah sistem jejaring sosial yang mengemuka di dalam masyarakat. Sebagai sebuah konsep, panopticon ini masih memungkinkan teraplikasi dalam banyak ranah di masa kini, baik di sektor formal birokrasi pemerintahan maupun swasta, di berbagai jenis media, di berbagai jenis bidang seperti ekonomi berbasis digital/internet misalnya.
Peneliti sebagai peneliti memfokuskan penelitian peneliti pada konsep panopticon yang mengemuka dalam organisasi wanita yang memiliki banyak anggota, guna mengawasi dan mendisiplinkan anggotanya. Peneliti melakukan penelitian panopticon yang terjadi di organisasi Bhayangkari. Bhayangkari merupakan salah satu organisasi wanita terbesar di Indonesia. Bhayangkari adalah persatuan istri anggota Polri dan menjadi badan ekstra/ di luar struktural Polri, di mana secara organisasional Bhayangkari mempunyai ruang lingkup nasional. Secara garis besar, tujuan utama dari organisasi ini adalah membantu meningkatkan dan memelihara kesejahteraan keluarga Polri (Juklak Bhayangkari, 2011) 
Idealnya, Organisasi Bhayangkari ini mampu menjadi wadah bagi perempuan yang tergabung di dalamnya untuk menemukan dan mengembangkan potensi yang dimiliki, meningkatkan kapasitas perempuan baik di bidang manapun dalam kehidupan, membina perempuan yang berada di dalamnya untuk memperoleh keahlian yang baru, menjadikan perempuan yang memiliki disiplin ilmu dibidangnya, berakhlak, beretika, cakap teknologi serta mampu bersaing di dunia global.

Namun demikian, Organisasi Bhayangkari pada kenyataannya masih sibuk dengan urusan internalnya sendiri, inilah yang justru menjadikan Bhayangkari berbanding terbalik dengan tujuan utama dibentuknya Organisasi. Para perempuan di dalam Organisasi ini, secara tak sadar menerima kekerasan yang dinamakan kekerasan simbolik dan terus menerus diawasi. Mereka sama sekali tidak merasa menjadi "korban kekerasan" karena terjadi internalisasi nilai-nilai yang diyakini sebagai kebenaran dan aturan yang mengikat di dalam Organisasi ini.

Bhayangkari memiliki aturan-aturan dan norma yang mengikat anggotanya di antaranya yakni aturan tertulis Bhayangkari yang sudah tertulis pada Juklak Bhayangkari. Juklak ini mengatur tentang sistem kepengurusan, keanggotaan, struktur organisasi, atribut dan seragam. Aturan-aturan sistemik ini akan selalu disosialisasikan kepada calon Bhayangkari ketika mereka menjalani sidang BP4 atau disebut sidang nikah dinas. Sidang nikah dinas adalah syarat mutlak yang harus dilaksanakan oleh setiap anggota polri dan calon bhayangkari guna melangkah ke jenjang pernikahan. Sidang ini berupa pemberian izin nikah dari pimpinan kepada setiap anggota yang akan melaksanakan pernikahan. Sidang yang harus dihadiri orang tua ini wajib dilaksanakan bagi seluruh personel beserta calon pasangannya, karena merupakan syarat yang harus dipenuhi oleh kedua calon untuk kelengkapan berkas pengajuan pernikahan di KUA atau catatan sipil .

Bagaimanapun, Bhayangkari, seperti halnya organisasi-organisasi perempuan yang ada dan berkembang dan "direstui" di jaman Orde Baru, tidak akan luput dari garis-garis utama tujuan dari pemerintahan kala itu. Organisasi-organisasi perempuan akan selalu menanggung "peran ganda" sebagai bagian dari pendukung pemerintahan yang kala itu memiliki ambisi besar dalam pembangunan (Julia Suryakusuma, 2011).

Untuk norma yang tidak tertulis, terdapat kebiasaan yang pada akhirnya menjadi norma yang mengatur bagaimana cara berkomunikasi dengan anggota Bhayangkari lainnya, mengatur bagaimana bersikap dan harus bertindak sebagai anggota Bhayangkari. Pelaksanaan organisasi ini berdasarkan jabatan suami, jika suami memiliki jabatan paling tinggi maka istrinya akan secara langsung menjadi ketua Bhayangkari yang membawahi istri-istri anggota Polri.

Penetapan jabatan dalam struktur organisasi Bhayangkari ini berdasarkan pangkat dan jabatan suami yang secara tidak langsung menjadikan Bhayangkari sebagai organisasi formal yang posisinya tergantung pada jabatan dan pangkat suaminya.

Organisasi Bhayangkari merupakan sebuah contoh beroperasinya konsep panopticon yang diinternalisasi dari awal bahkan sebelum masuk Organisasi ini yaitu terdapat beberapa kode dan aturan tidak tertulis 
yang membuat perempuan akan terus menerus diawasi.

Secara tidak langsung, pengawasan, dan pemeriksaan pada calon anggota Bhayangkari merupakan kekerasan simbolik, dimana korban tidak merasa bahwa dia sedang mengalami kekerasan, namun justru merasa bangga akan identitasnya sebagai Bhayangkari. Penelitian ini bertujuan untuk melihat:

1. Bagaimanakah pola komunikasi di dalam organisasi Bhayangkari.

2. Bagaimanakah proses normalisasi konsep panopticon atas komunikasi antar anggota sesama anggota Bhayangkari.

\section{TUJUAN PENELITIAN}

Berdasarkan rumusan masalah diatas, tujuan penelitian ini adalah untuk

1. Menganalisis pola komunikasi di antara anggota dalam organisasi Bhayangkari

2. Menganalisis proses komunikasi sebagai bentuk normalisasi konsep panopticon yang terjadi dalam Organisasi Bhayangkari

\section{TINJAUAN PUSTAKA}

Penelitian terkait dengan isu yang ada dalam artikel ini diantaranya yang dilakukan oleh Aryati Prautami (2015) yang berjudul Memahami Modalitas Perempuan Dalam Speech Codes Organisasi Persatuan Istri Prajurit Tni AD (Persit Kartika Chandra Kirana). Penelitian dilakukan dengan metode etnografi kritis dengan menggunakan prespektif Speech Codes Theory, merupakan penggabungan ide-ide yang berhubungan dengan bagaimana orang berpikir ketika berinteraksi dengan lingkungan sosialnya (constructivist) atau ten- tang bagaimana makna diperoleh secara sosial (constructionist) dan dipengaruhi oleh struktur kekuasaan dalam masyarakat, serta konsekuensi etis dari pilihan masyarakat (critical). Tujuan penelitian ini ingin melihat bagaimana speech codes dalam komunitas Persit untuk memahami penggunaan modalitas lain selain modal simbolik (jabatan dan pangkat suami) yang dimiliki oleh anggota Persit dalam speech codes organisasi istri TNI yang dimana organisasi istri tersebut sangat berorientasi kepada suami. Fokus dari penelitian ini adalah memahami cara berkomunikasi di dalam komunitas Persit, dan ingin melihat bagaimana anggota Persit memanfaatkan modal yang dimilikinya dalam speech codes organisasi Persit sehingga anggota Persit ini diposisikan secara informal berbeda dan tidak terlalu paralel dengan jabatan dan pangkat suami. Perbedaan hasil penelitian Prautami (2015) dengan penelitian ini adalah, penelitian sebelumnya ini hanya terfokus pada bagaimana Organisasi wanita memiliki kode-kode yang penelitian sebelumnya ini hanya terfokus pada bagaimana Organisasi wanita memiliki kode-kode yang hanya dipahami oleh anggota di dalamnya, bagaimana keterlibatan setiap anggota Organisasi agar dapat masuk dan diterima didalam sebuah Organisasi wanita pendamping suami akan lebih diperdalam di dalam penelitian yang peneliti lakukan.

Sementara itu Roekhan (2011) meneliti tentang kekerasan simbolik di sekolah. Penelitian ini melihat bagaimana kekerasan simbolik terjadi dalam sebuah institusi pendidikan bernama sekolah. Dari penelitian ini diperoleh hasil bahwa Panjangnya masa timbulnya pengaruh kekerasan simbolik terhadap pembentukan sikap dan perilaku (karakter) anak karena 
pengaruh itu terjadi secara bertahap. Pertama, anak menerima pajanan nilai-nilai negatif di sekitarnya secara terus-menerus. Kedua, siswa mempersepsi nilainilai negatif tersebut sebagai nilai-nilai yang positif dan layak untuk ditiru. Persepsi positif ini akan semakin kuat kalau penerapan nilai-nilai negatif tersebut dilakukan oleh orang dewasa yang mereka teladani, seperti guru dan orang tua. Ketiga, anak memasukkan dan menyimpan nilai-nilai negatif tersebut menjadi bagian dari nilai-nilai positif dalam dirinya. Dengan kata lain, nilai-nilai negatif tersebut dipersepsi dan diterima oleh siswa sebagai nilai yang positif (baik). Keempat, siswamenerapkan nilai-nilai negatif tersebut dalam perikehidupan mereka seharihari, baik di sekolah maupun di luar sekolah. Pada tahap inilah nilai-nilai negatif yang dipajankan melalui kekerasan simbolik tersebut telah menjadi bagian dari karakter siswa. Perbedaan hasil penelitian Prautami (2015) dengan penelitian ini adalah, penelitian sebelumnya ini hanya terfokus pada bagaimana Organisasi wanita memiliki kode-kode yang hanya dipahami oleh anggota didalamnya, bagaimana keterlibatan setiap anggota Organisasi agar dapat masuk dan diterima didalam sebuah Organisasi wanita pendamping suami akan lebih di perdalam didalam penelitian yang peneliti lakukan.

Penelitian Nurhayati Hasnah (2015) yang berjudul Representasi Kekerasan Simbolik pada Tubuh Perempuan dalam Media Massa Online Khusus Wanita (Studi Kasus Pada Rubrik Fashion dan Beauty Website Wolipop). Penelitian ini melihat bagaimana kekerasan simbolik terjadi dalam sebuah media baru yaitu internet. Banyaknya informasi dominan yang diberikan secara halus dalam Wolipop mengenai gaya hidup, fashion, dan kecantikan telah memberikan definisi yang berbeda terhadap makna tubuh perempuan melalui representasi yang diberikan. Representasi tubuh perempuan menempatkan perempuan sebagai objek eksploratif dan objek penekanan secara psikologis yang membatasi gerak perempuan dan menimbulkan kekerasan simbolik terhadap perempuan. Penelitian ini bertujuan mendeskripsikan representasi tubuh perempuan dalam rubrik fashion dan beauty website Wolipop, mendeskripsikan habitus dominan yang terdapat pada rubrik fashion dan beauty website Wolipop, menganalisis kekerasan simbolik pada tubuh perempuan dalam fashion dan beauty websiteWolipop. Metode penelitian yang digunakan dalam penelitian ini berupa metode analisis semiotika sosial dari Halliday dengan pendekatan secara kualitatif untuk melihat makna dibalik sebuah tanda, tanda dalam hal ini adalah berupa teks dan gambar pada artikel rubrik fashion dan beauty website Wolipop. Perbedaan penelitian ini dengan penelitian yang dilakukan oleh penulis Penelitian ini dipilih karena sasaran dari kekerasan simbolik dalam hal ini adalah perempuan, dengan berbagai cara dan media kekerasan simbolik menerpa perempuan dan tubuh perempuan.

\section{METODOLOGI PENELITIAN}

Penelitian tentang memahami konsep Panopticon yang didalamnya terdapat Simbolik Violence ini merujuk pada paradigma critical constructivist. Metode Critical constructivist ini meneliti bahwa pengetahuan merupakan hasil dari konstruksi sosial. Masyarakat secara sosial dikonstruksi oleh individu-individu yang memiliki kekuatan atau kekuasaan sehingga dapat meminggirkan orang lain dari masyarakat tersebut (Kincheloe, $2008: 3$ ). 
Ketika berinteraksi dalam lingkungan

sosialnya, makna yang diperoleh dipengaruhi oleh struktur kekuasaaan dalam masyarakat. Anggota Bhayangkari berada dalam lingkungan semi-militer yang mempengaruhi bagaimana anggota Bhayangkari ini berinteraksi dalam kelompoknya. Penelitian ini menggunakan metode critical constructivist karena ingin melihat bagaimana anggota Bhayangkari dalam berperilaku, berbicara dan bertindak sesuai dengan lingkungan sosialnya yang sangat hierarkis.

\section{Metode Penelitian}

Penelitian ini menggunakan studi kasus tunggal holistik (Creswell, 2007) yakni penelitian yang menempatkan sebuah kasus sebagai fokus dari penelitian. Sebagaimana disampaikan Yin (2009) ada 5 (lima) alasan untuk menggunakan hanya satu kasus di dalam penelitian studi kasus, yaitu:

a. Kasus yang dipilih mampu menjadi bukti dari teori yang telah dibangun dengan baik. Teori yang dibangun memiliki proposisi yang jelas, yang sesuai dengan kasus tunggal yang dipilih sehingga dapat dipergunakan untuk membuktikan kebenarannya.

b. Kasus yang dipilih merupakan kasus yang ekstrim atau unik. Kasus tersebut dapat berupa keadaan, kejadian, program atau kegiatan yang jarang terjadi, dan bahkan mungkin satu-satunya di dunia, sehingga layak untuk diteliti sebagai suatu kasus.

c. Kasus yang dipilih merupakan kasus tipikal atau perwakilan dari kasus lain yang sama. Pada dasarnya, terdapat banyak kasus yang sama dengan kasus yang dipilih, tetapi dengan maksud untuk lebih menghemat waktu dan biaya, penelitian dapat dilakukan hanya pada satu kasus saja, yang dipandang mampu menjadi representatif dari kasus lainnya.

d. Kasus dipilih karena merupakan kesempatan khusus bagi penelitinya. Kesempatan tersebut merupakan jalan yang memungkinkan peneliti untuk dapat meneliti kasus tersebut. Tanpa adanya kesempatan tersebut, peneliti mungkin tidak memiliki akses untuk melakukan penelitian terhadap kasus tersebut.

e. Kasus dipilih karena bersifat longitudinal, yaitu terjadi dalam dua atau lebih pada waktu yang berlainan. Kasus yang demikian sagat tepat untuk penelitian yang dimaksudkan untuk membuktikan terjadinya perubahan pada suatu kasus akibat berjalannya waktu..

Sementara itu, subyek penelitian ini adalah anggota Bhayangkari Daerah Jawa Tengah. Peneliti melakukan wawancara mendalam dengan anggota Bhayangkari. Selain itu peneliti juga akan melakukan observasi partisipatif (Sugiyono, 2009: 227). Peneliti terlibat dan mengamati bagaimana anggota Bhayangkari Cabang Pekalongan berinteraksi dengan anggota lainnya

\section{Teknik Analisis Data}

Teknik analisis data pada case study terdiri dari proses pengumpulan data, tabulasi(olah data), dan menguji data dengan teori. (1) penjodohan pola, yaitu dengan menggunakan logika penjodohan pola. Logika seperti ini membandingkan pola yang didasarkan atas data empirik dengan pola yang diprediksikan (atau 
dengan beberapa prediksi alternatif). Jika kedua pola ini ada persamaan, hasilnya dapat menguatkan validitas internal studi kasus yang bersangkutan; (2) pembuatan eksplanasi, yang bertujuan untuk menganalisis data studi kasus dengan cara membuat suatu eksplanasi tentang kasus yang bersangkutan dan (3) analisis deret waktu, yang banyak dipergunakan untuk studi kasus yang menggunakan pendekatan eksperimen dan kuasi eksperimen.

\section{TEMUAN DAN DISKUSI}

\section{Komunikasi Antar Pribadi: dari komunikasi} satu arah menjadi komunikasi dua arah

Dalam bab ini akan peneliti jabarkan mengenai tata cara berkomunikasi dalam organisasi Bhayangkari di mana itu nantinya menjadi area tempat panopticon mengemuka sebagai sebuah konsep pengawasan dalam jejaring media komunikasi. Nantinya pola-pola konsep panopticon yang muncul atau termanifestasi dalam wujud tindakan atau tatacara atau habitus akan dijelaskan dalam bentuk time series individu. Sebelum meneliti lebih jauh pola-pola komunikasi tersebut, penting peneliti paparkan lebih dulu bagaimana komunikasi yang dilakukan oleh para anggota Bhayangkari selama ini. Adapun detail pemaparannya adalah seperti berikut:

Pola komunikasi satu arah ini sudah berlangsung sejak berdirinya organisasi Bhayangkari. Jika dalam diktum komunikasi tujuan dari komunikasi adalah penyampaian pesan, maka ilustrasi dari prosesi penyampaian pesan terjadi secara vertikal dari atas ke bawah. Ini berarti pesan dikirimkan oleh ibu ketua umum yang berarti pemegang kekuasaan tertinggi, untuk diteruskan kepada yang berada di bawahnya yakni ibu ketua daerah. Kemudian ibu ketua daerah meneruskan kepada ketua cabang dan ketua cabang meneruskan kepada ketua ranting, selanjutnya ketua ranting akan meneruskan kepada seluruh anggota. Dengan pola komunikasi vertikal seperti ini pesan bisa dimaknai sebagai konotasi atas sebuah perintah atau mandat, yang secara tak langsung keberadaannya tidak bisa dibantah ataupun dikritik. Pesan komunikasi hanya bisa diterima dan dilaksanakan oleh seluruh anggota Bhayangkari dari pusat sampai ke ranting dengan kesediaan mutlak.

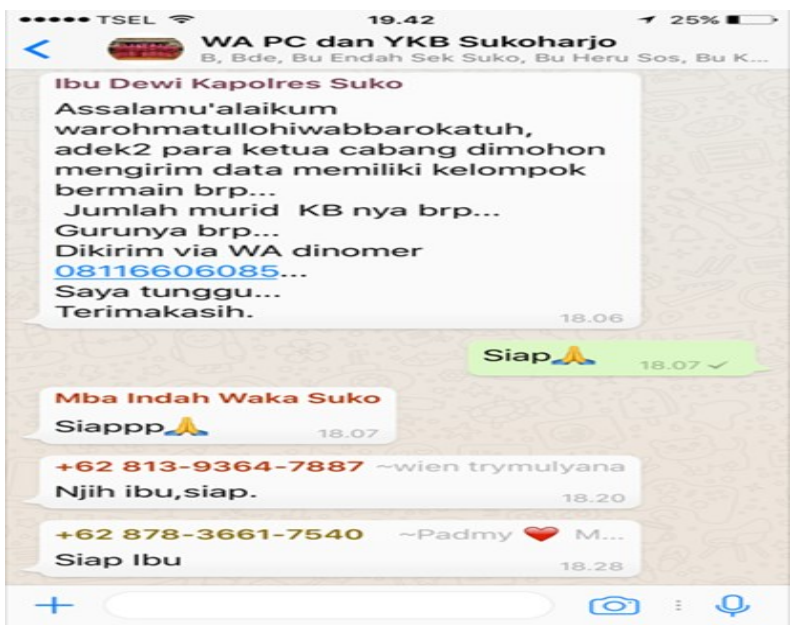

Gambar 1

\section{Contoh Komunikasi Satu Arah}

Komunikasi satu arah seperti pada contoh gambar di atas masih berlaku untuk topik yang bersifat umum misalnya perintah untuk melakukan persiapan acara dan pemberitahuan tentang informasi mengenai agenda yang akan dihelat oleh organisasi. Ada pun pola satu arah vertikal ini menjadi habitus dalam organisasi Bhayangkari dalam waktu yang lama karena bagi beberapa pelaku komunikasi di Bhayangkari, terkhusus anggota-anggota yang memiliki jabatan tinggi dari suaminya, dianggap relatif efisien dan mampu memini- 
malkan adanya noise pelaku komunikasi lainnya.

Kelebihan komunikasi satu arah yaitu:

1. Lebih cepat dan efisien.

2. Dalam hal-hal tertentu dapat memberikan kepuasan kepada komunikator, karena pihak komunikan tidak mempunyai kesempatan untuk memberikan respons atau tanggapan terhadap hal-hal yang disampaikan oleh komunikator.

3. Dapat memunculkan nila/citra kewibawaan bagi komunikator (pimpinan), karena komunikasi tidak dapat mengetahui secara langsung atau menilai kesalahan dan kelemahan komunikator.

4. Suasana pada saat penyampaikan pesan atau informasi lebih tentram dan teratur.

5. Yang berbicara hanya ada satu orang sehingga penerima pesan atau penyimak lebih mudah mencerna dan memahami pesan yang disampaikan.

6. Dapat mempengaruhi orang lain melalui pesan yang disampaikan atau informasi yang disampaikan.

7. Pembicara bebas menyampaikan apa yang ingin disampaikan.

8. Pesan yang disampaikan pembicara lebih faktual dan dapat dipercaya.

Kelemahan komunikasi satu arah yaitu:

1. Tidak memberikan kepuasan kepada komunikan, karena komunikan tidak mempunyai kesempatan untuk memberikan respons atau tanggapan.

2. Memberikan kesan otoriter bagi pengirim pesan.

3. Dapat menimbulkan kesalahpahaman dan ketidakjelasan, sehingga muncul prasangka yang tidak baik.

4. Penyimak bisa saja memahami apa yang disam- paikan pembicara karena penyimak tidak boleh merespon atau memberikan tanggapannya kepada pembicara, sehingga pembicara tidak mengetahui apakah semua penerima pesan atau penyimak memahami seluruh isi pesan yang disampaikan pembicara atau tidak memahami, jadi walaupun penerima pesan mau memberikan tanggapan cukup kepada diri sendiri,

5. Terkadang penyimak tidak peduli akan apa yang disampaikan pembicara karena penerima pesan merasa bosan.

Dalam orde pemerintahan Joko Widodo organisasi Bhayangkari banyak mengalami perubahan aturan. Pola kebiasaan berkomunikasi yang tadinya sangat kuno dan ketat lambat laun mengalami perubahan yang signifikan. Anggota Bhayangkari mulai diperbolehkan menyampaikan pertanyaan dan pernyataan, memberikan kritik maupun saran dengan leluasa. Kesan luwes dan inklusif pun bisa dilihat ketika Ibu Ketua menjalankan aktivitasnya di luar ruangan. Misalnya Ibu ketua sudah tidak lagi dipayungi ketika berjalan dalam sebuah perhelatan non formal serta tidak menginginkan dilayani dengan layanan protokoler yang berkesan mewah dan ekslusif. Kebiasaan-kebiasaan ini secara tidak langsung, meski tak tertulis menjadi sebuah regulasi, pelan-pelan menjadi patron baru bagi para anggota Bhayangkari.

Pada masa pemerintahan Joko Widodo pola komunikasi di Bhayangkari telah mengalami petuhanan menjadi pola komunikasi dua arah, komunikasi dua arah dimana ketika seseorang mengirim pesan, mengeluarkan ide, gagasan, pendapat dan penerima pesan (pendengar) menanggapi isi pesan atau komunikasi dua 
arah merupakan komunikasi yang berlangsung antara dua pihak dan ada timbal balik baik dari komunikator maupun komunikan. Pola komunikasi dua arah digambarkan dalam bentuk gambar sebagai berikut:

Dengan demikian, saat ini mulai terjadi komunikasi dua arah di dalam organisasi Bhayangkari, dimana terjadi transaksional pesan dari pengirim pesan dan penerima pesan, terdapat musyawarah, rapat dan anggota mulai diperbolehkan untuk menyatakan pendapatnya.

\section{Kegagalan Beradaptasi}

Hal ini terjadi pada informan pertama dalam penelitian ini yakni Feny. Feny adalah seorang perempuan berusia 25 tahun. Dia adalah istri Polisi yang berpangkat AKP, dia berpendidikan SMU dan ibu rumah tangga biasa dalam aktivitasnya. Dalam Bhayangkari dia tidak menjabat sebagai pengurus dan tidak aktif sebagai anggota Bhayangkari, seperti yang ditunjukkan dalam tabel dan grafik sebagai berikut :

\begin{tabular}{|c|l|l|}
\hline $\begin{array}{c}\mathrm{N} \\
\mathrm{o}\end{array}$ & \multicolumn{1}{|c|}{ Aktivitas } & \multicolumn{1}{|c|}{ Keterangan } \\
\hline 1. & Perkenalan & Pada Tahun 2013 \\
\hline 2. & $\begin{array}{l}\text { Tidak nyaman berada } \\
\text { di lingkungan Bha- } \\
\text { yangkari }\end{array}$ & Tahun 2013 \\
\hline 3. & $\begin{array}{l}\text { Tidak aktif sebagai } \\
\text { anggota Bhayangkari }\end{array}$ & Tahun 2014 \\
\hline
\end{tabular}

Tabel 1

\section{Individu Feny}

Sumber : Bhayangkari, 2017

\section{a. Adaptasi Awal}

Feny (25) kali pertama bergabung dalam organisasi Bhayangkari pada tahun 2013. Ketika awa-awal masa perkenalan menjadi anggota Bhayangkari, informan 1 ini sudah merasa tidak nyaman menjadi anggota organisasi. Menurut Feny, faktor senioritasyunioritas dalam organisasi Bhayangkari membuatnya tidak nyaman ketika masuk dalam sistem komunikasi antar anggota Bhayangkari. Dia selanjutnya paham bahwa sistem hierarki senior-yunior berdasarkan jabatan dan pangkat suami secara otomatis juga membentuk hierarki posisi sosial anggota Bhayangkari. Sistem hierarki militeristik menempatkan suaranya sebagai individu yang semestinya memiliki kebebasan menjadi tidak ada. Ketika dirinya berhadapan/berkomunikasi dengan perempuan lain yang notabene adalah isteri dari seorang polisi dengan jabatan yang lebih tinggi dari jabatan suaminya di kepolisian, maka yang terjadi selanjutnya adalah komunikasi searah, dan suara Feny hanya akan menjadi suara penyepakat/ The Yes Woman Voice.

\section{b. Ketidaknyamanan}

Informan 1 merasa tidak nyaman sejak pertama kali bergabung di organisasi Bhayangkari selain faktor senioritas, dia merasa tidak bisa berkomunikasi dengan baik dengan anggota Bhayangkari lainnya terutama dengan anggota Bhayangkari yang sudah senior dan pangkat suaminya jauh di atas pangkat suami informan. Informan merasa tidak nyaman karena selama dalam lingkungan Bhayangkari dia beberapa kali mendapatkan teguran dari Ibu Ketua Umum terkait dengan penampilan dirinya yaitu seragam yang terlalu ketat dan juga suka pamer di Media Sosial. Feny berpikir bahwa teguran yang diarahkan kepadanya terlalu mengada-ngada sehingga dia merasa tidak nyaman berada di organisasi Bhayangkari. Proses pengawasan yang terjadi terus-menerus dan merujuk pada wilayah- 
wilayah privat milik Informan 2 inilah yang menurut peneliti adalah manifestasi dari konsep panopticon. Pengawasan diarahkan seperti halnya sebuah tatapan yang tidak hanya menyangkut urusan general (dalam konteks ini adalah agenda-agenda atau kegiatan Bhayangkari), tapi sudah masuk ke area-area yang semestinya menjadi hak opsional bagi individu akan memilih berhabitus seperti apa. Seolah kehidupan pribadi anggota organisasi, secara tidak tertulis ikut diatur oleh Bhayangkari.

\section{c. Penarikan Diri}

Dengan alasan ketidaknyamanan, Informan1 selanjutnya, mulai mengurangi aktivitas di media sosial dan mengurangi porsi komunikasinya dengan anggota Bhayangkari lainnya. Pada beberapa kegiatan dia mulai tidak mengikuti. Dan pada tahun 2014 Feny sama sekali tidak aktif lagi dalam kegiatan Bhayangkari.

Dari uraian diatas dapat disimpulkan dalam gambar grafik individu Feny yang berawal dari

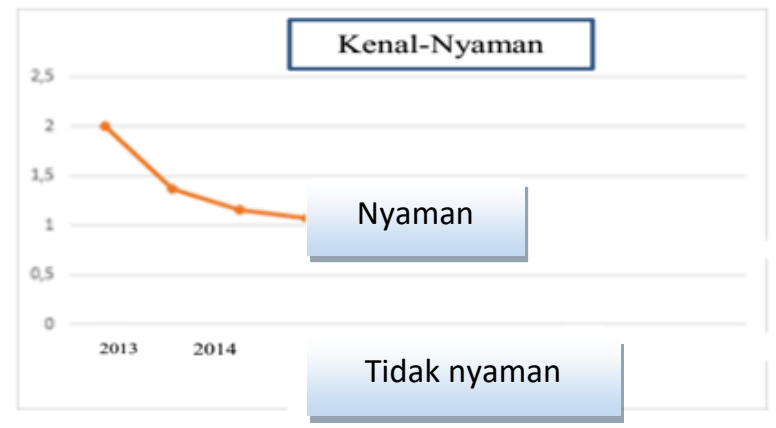

Gambar 2

Individu Feny

Sumber : Data Primer Diolah, 2017

Pada awal menjadi anggota Bhayangkari pada tahun 2013 Feny cukup mengalami kesulitan berada di lingkungan organisasi Bhayangkari. Faktor senioritas dalam organisasi Bhayangkari cukup nampak selain itu berdasarkan jabatan dan pangkat suami, posisi sosial anggota Bhayangkari. Sejak masa perkenalan tahun 2013 aktif sampai dengan tahun 2014 sebagai anggota Bhayangkri namun dia tidak merasa nyaman bergabung sebagai anggota istri polisi dan memilih untuk tidak aktif sebagai anggota

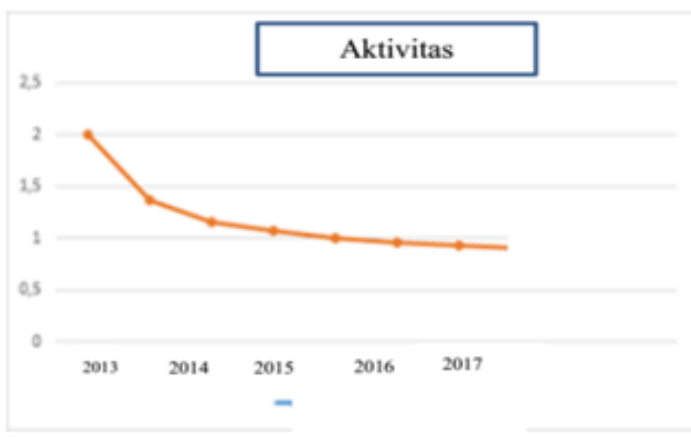

Gambar 3

Aktivitas Individu Feny

Pada awal menjadi anggota Bhayangkari, Informan1 cukup mengalami kesulitan berada di lingkungan organisasi Bhayangkari. Faktor senioritas dalam organisasi Bhayangkari cukup nampak selain itu berdasarkan jabatan dan pangkat suami, posisi sosial anggota Bhayangkari. Feny tidak merasa nyaman dalam organisasi Bhayangkari. dia kerap ditegur oleh Ibu Ketua Bhayangkari karena dinilai menggunakan seragam Bhayangkari yang ketat dan suka pamer di Media Sosial Bhayangkari.

Komunikasi yang dia jalin dengan anggota Bhayangkari lainnya tidaklah banyak, kecuali untuk topik-topik formal yang meliputi pembahasan mengenai tempat liburan untuk perpisahan dengan Ibu Ketua yang lama, pakaian untuk HUT POLRI dan lainlain. Tetapi secara garis besar topik pembicaran yang sering dibahas dalam Bhayangkari adalah mengenai kegiatan Bhayangkari seperti mengenai program kerja Bhayangkari sedangkan topik informal yang dibicakan 
seperti Topik pembicaraan lain muncul ketika kegiatan Bhayangkari adalah masalah pribadi seperti masalah perawatan wajah, masalah kesehatan suami dan anak serta membicarakan masalah yang terkait dengan keadaan masing-masing anggota Bhayangkari. Topik pembicaraan ini lebih banyak muncul ketika ada kegiatan santai.

Feny tidak berani mengemukakan pendapatnya ketika ibu ketua atau ibu wakil meminta saran ke forum, sebagaimana anggota lain Bhayangkari akan memberikan saran ketika ibu ketua meminta saran kepada anggotanya. Jika ibu ketua telah memutuskan sesuatu maka Informan1 ini tidak akan berani untuk memberikan saran.

Informan1 beberapa kali mendapatkan teguran baik dalam bentuk tertulis atau dalam bentuk lesan secara langsung saat berada di dalam forum pertemuan Bhayangkari sehingga dia merasa dia tidak bisa beradaptasi atau menyesuaikan diri di lingkungan Bhayangkari. Dia merasa teguran yang diberikan kepadanya terlalu mengada-ada dan dibuat-buat sehingga dia memilih untuk tidak aktif berada di lingkungan Bhayangkari.

\section{Anggota yang berhasil beradaptasi}

Sementara itu anggota yang berhasil beradaptasi dengan polt komunikasi yakni informan kedua dalam penelitian ini adalah Chania, Chania adalah seorang perempuan berusia 26 th dia adalah istri Polisi yang berpangkat Iptu, dia berpendidikan profesi, Feny adalah wanita karier yang berprofesi sebagai dokter. Dalam Bhayangkari pada awalnya dia tidak menjadi pengurus Bhayangkari ketika suaminya masih bertugas di Aceh. Setelah suaminya menjabat sebagai Kapolsek
Semarang Timur Chania memegang menjabat sebagai pengurus Bhayangkari Sie Kebudayaan di Bhayangkari Kendal, kemudian menjabat sebagai Ketua Ranting di Bhayangkari Semarang, seperti yang ditunjukkan dalam tabel dan grafik sebagai berikut :

\begin{tabular}{|c|l|l|}
\hline No & \multicolumn{1}{|c|}{ Aktivitas } & \multicolumn{1}{|c|}{ Keterangan } \\
\hline 1. & Perkenalan & $\begin{array}{l}\text { Pada Tahun } \\
2013\end{array}$ \\
\hline 2. & $\begin{array}{l}\text { Nyaman berada } \\
\text { di lingkungan } \\
\text { Bhayangkari }\end{array}$ & Tahun 2013 \\
\hline 3. & $\begin{array}{l}\text { Aktif sebagai } \\
\text { pengurus Bha- } \\
\text { yangkari }\end{array}$ & Tahun 2014 \\
\hline
\end{tabular}

Tabel 2

Individu Chania

Sumber : Bhayangkari, 2017

\section{a. Masa Adaptasi}

Chania (26) pertama kali bergabung dalam organisasi Bhayangkari pada tahun 2013. Awal masa perkenalan Feny (25) sudah belum nyaman menjadi anggota Bhayangkari namun dengan segera Chania pada pertemuan kedua dan ketiga sudah bisa membawa diri. dia bisa berkomunikasi dengan baik dengan sesama anggota Bhayangkari lain yang seangkatan maupun yang lebih senior. Dia membuka diri untuk belajar dan menerima berbagai macam kritik dan saran.

Bahkan Chania mencari berbagai informasi mengenai organisasi Bhayangkari dengan bertanya kepada suami, kepada rekan di organisasi Bhayangkari dan juga juklak menganai tata aturan di Bhayangkari.

\section{b. Merasa Nyaman}

Informan2 merasa nyaman saat pertemuan ke dua di Bhayangkari. Saat suami pindah tugas 
ke jateng dan penempatan polres sudah mulai di cari, dan harus menyesuaikan. dia bisa melakukan komunikasi dengan baik dalam pertemua ke dua, bisa berinteraksi dengan anggota Bhayangkari lainnya dan dapat membaur. Komunikasi yang terjalin antara informan2 dengan anggota Bhayangkari lainnya antara lain sangat baik dari komunikasi informal. Ada pun rasa nyaman yang diterima oleh Chania bagi peneliti terpengaruh juga dengan situasi/kultur organisasi, yang memang mayoritas anggotanya, akan selalu bangga dengan atribut sosial mereka sebagai istri anggota/pejabat polisi. Menjadi anggota Bhayangkari secara tidak langsung dirasakan sebagai penaik tingkatan status sosial bagi para anggotanya. Kultur yang berlangsung cukup lama ini menghasilkan efek bahwa mereka, para anggota Bhayangkari, untuk melegitimasi posisi sosial mereka, maka mereka perlu untuk menunjukkan eksistensi mereka sebagai istri seorang polisi dengan "mendisplay" seragam kebanggaan mereka.

\section{c. Aktif sebagai anggota Bhayangkari}

Dari mulai tahun 2013 hingga 2017 meskipun memiliki profesi sebagai Dokter di luar tugasnya sebagai istri Polisi. Chania aktif sebagai anggota Bhayangkari pada tahun 2013 dia hanya sebagai anggota Bhayangkari saat suaminya bertugas di Aceh kemudian pada tahun 2014 menjabat sebagai Sie Kebudayaan saat suaminya bertugas sebagai Kasat Reskrim di Kendal. Saat ini Chania menjadi Ketua Ranting (2017). Kasat Reskrim di Kendal. Saat ini Chania menjadi Ketua Ranting (2017).

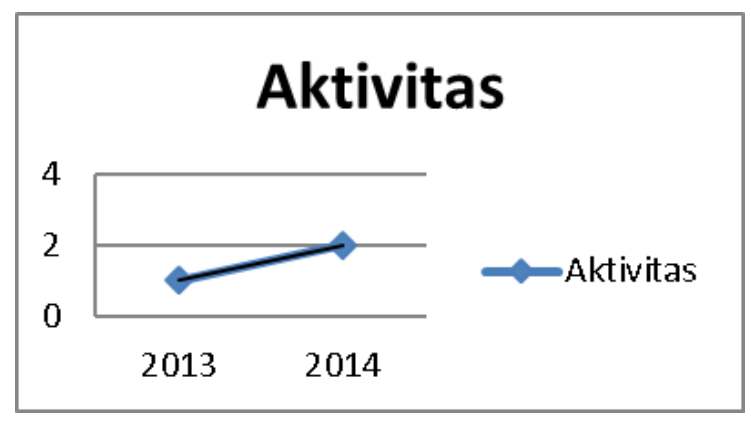

Gambar 4

Individu Chania

Sumber : Data Primer Diolah, 2017

Pada awal menjadi anggota Bhayangkari pada tahun 2013 Informan 2 juga cukup mengalami kesulitan berada di lingkungan organisasi Bhayangkari. Awalnya Informan2 tidak mengerti sama sekali mengenai organisasi bhayangkari, dari nikah kantor dijelaskan sedikit mengenai Bhayangkari itu apa, termasuk tugas suami, tugas istri, dan harus gimana jadi istri polisi. Pada awalnya masih meraba-raba, namun kemudian bisa langsung merasa nyaman dalam bergaul dengan anggota lain sambari belajar organisasi dan berinteraksi dengan anggota lain yang lebih senior. Waktu yang dibutuhkan utk menyesuaikan diri cukup singkat dalam 2-3 kegiatan Informan2 sudah bisa berbaur dan merasa nyaman.

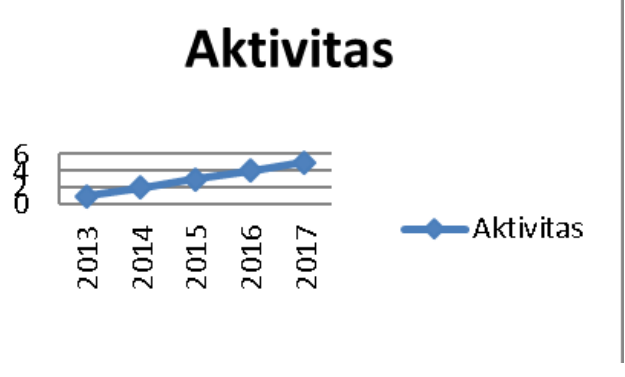

Gambar 5

Aktivitas Individu Chania

Sumber : Data Primer Diolah, 2017

Pada awal menjadi anggota Bhayangkari, 
Informan2 cukup mengalami kesulitan berada di lingkungan organisasi Bhayangkari. Namun dalam 2- 3 kali pertemuan dia bisa berbaur dan merasa nyaman. Mulai belajar organisasi dan berinteraksi dengan anggota Bhayangkari yang lebih senior dan ibu-ibu lainnya.

Komunikasi yang dijalin dengan anggota Bhayangkari lainnya selain komunikasi formal juga komunikasi informal. Topik formal yang dibahas seperti rencana pertemuan cabang atau ranting, mau diisi kegiatan apa yang sekiranya bermanfaat, snack atau makanan yang akan di sajikan. Sedangkan topik informal yang dibicarakan antara lain terkait dengan aktivitas sehari-hari seperti rencana jalan jalan, mau kemana, makan atau nonton, pakai dresscode apa, merencanakan surprise party untuk acara ulang tahun salah seorang Bhayangkari yang biasanya senior. dalam menyampaikan kritrik ataupun saran cukup hati-hati, kepada siapa kritik atau saran tersebut akan disampaikannya dan melihat dulu apakah orang tersebut memberikan peluang untuk menerima kritik ataupun saran. Apabila tidak dimita Informan2 akan memilih diam dan Akan menyampaikan saran dan kritik apabila diminta menyampaikan ya disampaikan saja dengan jujur sesuai kenyataan dan keadaan.

Informan2 pernah mendapatkan teguran, meskipun teguran yang diterimanya secara lesan, namun teguran itu menurutnya adalah teguran yang ringan seperti saat menjadi awal anggota Bhayangkari Chania menggunakan jam tangan warna kuning bukan hitam, kemudia rok seragam Bhayangkari ibu hamil belahannya di depan harusnya untuk ibu hamil di belakang. Namun teguran tersebut dianggapnya sebagai kritik yang membangun dalam prosesnya menjadi anggota Bhayangkari.
Dari data diatas diperoleh fakta bahwa pada umumnya anggota yang berhasil dalam melakukan komunikasi adalah anggota yang sederhana dan mudah bergaul baik dengan teman satu letting maupun dengan anggota lain yang lebih senior, pada umumnya Bhayangkari tipe ini adalah orang yang bisa menempatkan dirinya saat berada di dalam lingkungan Bhayangkari sehingga dia memiliki banyak teman baik yang seletting maupun dengan anggota lain yang lebih senior.

Penelitian ini juga menemukan bahwa pola duduk menjadi hal yang krusial menentukan keberhasilan dan kegagalan dalam berkomunikasi. Posisi duduk akan berpengaruh terhadap seberapa besar anggota Bhayangkari bisa berinteraksi dan seberapa aktif pembicaraan anggota Bhayangkari dengan anggota lainnya. Posisi duduk yang benar sangat berpengaruh terhadap fokus dan informasi dari teman bicara. (Allan \& Barbara, 2014)

Posisi duduk yang baik dan berhasil dalam menjalin komunikasi adalah tercipta interaksi yang baik dengan anggota lain baik seletting maupun dengan anggota Bhayangkari yang sudah senior. Seperti menyapa ibu Ketua Bhayangkari, duduk di depan ketika ada acara, dan menyapa dan mendekati anggota Bhayangkari lain saat diajak berinteraksi seperti gambar dibawah ini

Sementara posisi duduk yang tidak baik dan tidak berhasil menjalin komunikasi adalah ketika berada dalam suatu kegiatan informal maupun formal dalam organisasi Bhayangkari. Anggota Bhayangkari terlihat menghindari untuk duduk bersama dengan anggota Bhayangkari yang berpangkat perwira, seperti yang terlihat dalam gambar di bawah ini 


\section{Pola Komunikasi Organisasi}

Djamarah dalam bukunya Pola Komunikasi

(2004:1) adalah Pola komunikasi dapat dipahami sebagai pola hubungan antara dua orang atau lebih dalam pengiriman dan penerimaan pesan dengan cara yang tepat sehingga pesan yang dimaksud dapat dipahami. (2004:1)

Salah satu tantangan besar dalam menentukan pola komunikasi adalah proses yang berhubungan dengan peristiwa komunikasi komunikasi dan komponennya.

Peristiwa komunikasi dapat membantu menentukan iklim dan moral suatu kelompok, yang pada gilirannya akan berpengaruh pada jaringan komunikasi. Tantangan dalam menentukan pola komunikasi adalah bagaimana menyampaikan informasi keseluruh bagian anggota kelompok

Komunikasi sangat berperan dalan menumbuhkan kesejahteraan manusia baik dalam bidang kehidupan sehari-hari atau dalam sebuah organisiasi. Organisasi adalah sebuah kelompok individu yang di organisasikan untuk mencapai tujuan tertentu. Komunikasi organisasi adalah pengiriman dan penerimaan berbagai pesan organisasi di dalam kelompok formal maupun informal dalam suatu organisasi.bila dalam organisasi semakin besar dan kompleks maka akan mengakibatkan semakin kompleks pula proses komunikasinya.

Komunikasi organisasi dapat bersifat formal dan informal. Komunikasi formal adalah komunikasi yang disetujui oleh organisasi itu sendiri dan sifatnya berorientasi kepentingan organisasi. Sedangkan komunikasi informal adalah komunikasi yang disetujui secara social. Orientasinya bukan pada organisasi

\section{KESIMPULAN}

Penelitian ini dilakukan dengan latar belakang adanya kekerasan simbolik yang terus menerus beroprasi pada organisasi wanita "Bhayangkari" adanya dominasi dari istri pimpinan terhadap istri bawahan maupun dari istri senior kepada istri junior dipahami sebagai sesuatu yang wajar yang pada akhirnya diterima oleh seluruh anggota organisasi ini.

Anggota Bhayangkari harus mampu beradaptasi dengan iklim organisasi yang mewajibkannya untuk tunduk kepada pimpinan dan seniornya. permasalahan tersebut menuntun peneliti untuk melakukan penelitian yang bertujuan untuk menjelaskan bentukbentuk kekerasan simbolik didalam proses adaptasi dan komunikasi organisasi Bhayangkari, bagaimana kekerasan simbolik menjadi langgeng dan terus menerus diproduksi pada setiap lini organisasi hingga pada akhirnya dianggap sebagai sebuah kewajaran oleh anggotanya, selain itu penelitian ini juga bertujuan untuk menjelaskan konsep panoptikon di dalam organisasi Bhayangkari. Pencapaian tujuan-tujuan penelitian tersebut dilakukan dengan melakukan observasi langsung pada organisasi Bhayangkari dan hasil wawancara terkait proses adaptasi dan penyesuaian diri di dalam organisasi Bhayangkari.

Kekerasan simbolik merupakan penguasa atas wacana menjadikan sebuah dominasi sebagai sesuatu yang alamiah dan bisa diterima, Bahkan situasi paling menyiksa dan tak bisa ditolerir bisa tampak wajar, di dalam dominasi istri pimpinan di organisasi Bhayangkari ini, yang sebetulnya terjadi adalah kekerasan. Oleh Pierre Bourdieu kekerasan itu disebut kekerasan simbolik atau kekerasan yang tak kasat mata(1998:7). Kekerasan semacam ini oleh korbannya (anggota Bha- 
yangkari) bahkan tidak dilihat atau tidak dirasakan sebagai kekerasan, tetapi sebagai sesuatu yang alamiah dan wajar. Bahwa sebagai istri junior atau istri anggota harus tunduk terhadap berbagai macam perintah Istri Pimpinan diterima sebagai sesuatu yang sudah semestinya, segala perintah tidak perlu dipertanyakan lagi, segala jenis aturan harus diterima.

Pada dasarnya kekerasan simbolis berlangsung karena ketidaktahuan dan pengakuan dari yang ditindas. Jadi, sebetulnya logika dominasi ini bisa berjalan karena prinsip simbolis yang diketahui dan diterima baik oleh yang menguasai maupun yang dikuasai. Prinsip simbolis itu berupa bahasa, cara berpikir, cara bertindak yang khas pada kelompok didalam organisasi Bhayangkari.

Sesuai hasil penelitian ini maka dapat ditemukan beberapa bentuk-bentuk beroprasinya kekerasan simbolik yang didalamnya terdapat panoptikon atau pengawasan secara terus menerus dari para pimpinan organisasi Bhayangkari.

Proses kekerasan simbolik tersebut dilakukan dalam bentuk gaya berkomunikasi dan bertindak dimana istri junior akan menggunakan kata-kata "mohon ijin" "siap perintah" "siap salah" dan bagi istri pimpinan akan memberikan perintah yang wajib dilakukan.

Adapun bentuk panoptikon yang ditemukan oleh peneliti adalah pengawasan mulai dari awal seorang perempuan akan masuk menjadi anggota bhayangkari maka akan dilakukan beberapa tahapan tes seperti administrasi, tes kesehatan, dan akan dilaksanakan sidang BP4 yang didalamnya akan dibacakan riwayat hidup dan pendidikan juga riwayat keluarga calon anggota Bhayangkari tersebut, selain itu menikah dengan anggota Kepolisian maka harus mendapatkan ijin dari Kantor dan pimpinan, tidak sampai disitu saja, panoptikon masih terus berlanjut ketika seorang perempuan sudah menjadi anggota organisasi Bhayangkari, akan ada banyak mata yang selalu mengawasi gaya bahasa, gaya berpakaian, gaya hidupnya dan tingkah lakunya, juga di media sosial organisasi Bhayangkari memberlakukan cyber patrol yang digunakan untuk mengawasi sosial media istri angota POLRI dan kepadanya akan dikenakan teguran juga sanksi jika dianggap melanggar norma-norma yang berlaku.

\section{DAFTAR PUSTAKA}

Bertrand, Michel. (ed) (1996). Violence et Pouvoir Pilitiques. Toulouse: Pressses Universtitaines du Mirall

Blackburn, Susan. (2004). Women and The State in

Indonesia. Edinburgh: Cambridge University Press.

Bourdieu, Pierre. (2000). Le structures sosiales de l'economie. Paris: Seull.

Bourdieu, Pierre. (2001). Masculine Domination, translated from France by Richard Nice. StanfordCalif: Standford University Press.

Brossat, Alain. (1994). (ed). Michel Foucault: les jeux cle la verite et du pouvoir. Nancy: Presses

Universitaires de Nancy.

Daymon, C. And Holloway, I. (2002) Qualitative

Research Methodes in Public Relation and

Markedeting Communication. New York: Routledge. de Beauvoir, Simone. (2014) Second Sex-Kehidupan

Perempuan. Yogyakarta: Narasi + Pustaka

Promothea.

Fashri, Fauzi (2014). Pierre Bourdieu: Menyingkap 
Kuasa Simbol. Yogyakarta: Jalasutra.

Foucault, Michel. (1990). The Use of Pleasure:

Volume 2 The History of Sexuality. New York: Vintage

Books.

Foucault, Michel. (1990). The Use of Pleasure:

Volume 2 The History of Sexuality. New York: Vintage

Books.

Gidden, Anthony. (1984). The Constitution of Society.

Cambridge: Polity Press.

Haryatmoko, J. (1996). Le statut epistemelogique de

Verzseignement social de l'Eglise Catholique. Bern:

Peter Lang.

Lerner, Greda (1986) The Creation of Patriarchy. New

York: Oxford University Press.

McQuail,Dennis.(2011).TeoriKomunikasi

Massa.Jakarta: Penerbit Salemba Humanika.

Mulyana, Deddy (2013) Metodologi Penelitian

Kualitatif. Yogyakarta: Remaja Rosdakarya.

Putnam Tong, Rosemarie (1998) Feminist Thought:

Pengantar Paling Komprehensif kepada Arus Utama

Pemikiran Feminism. Yogyakarta: Jalasutra.

Suryakusuma, Julia. (2011). Ibuisme Negara:

Konstruksi Sosial Keperempuanan Orde Baru. Depok:

Komunitas Bambu.

W. Littlejohn, Stephen \& A Foss, Karen (2014). Teori

Komunikasi. Jakarta: Salemba Humanika.

Walby, Sylvia (1990) Theorizing Patriarchy. Oxford:

Basil Blackwell.

Wieringa, Saskia. (2002). Sexual Politic in Indonesia.

Hampshire: Palgrave Macmillan. 